\title{
IS IT IMPORTANT TO TEACH LITHUANIAN CHILDREN SWIMMING? ANALYSIS OF DROWNING AND SCHOOLCHILDREN'S KNOWLEDGE OF SAFE CONDUCT AT THE WATER
}

\author{
Ilona Judita Zuozienė, Gintarė Akelytė, Aurelijus Kazys Zuoza \\ Lithuanian Sports University, Kaunas, Lithuania
}

\begin{abstract}
Background. Research aim was to investigate statistical data of children and youth's (19 years old and under) deaths from drowning in the period from 2000 to 2012, as well as to establish the I-IVth form students' selfassessment of swimming skills and knowledge of safe swimming and safe conduct at the water.

Methods. Statistical data analysis and questionnaire survey methods were used in the research. The content of the questionnaire consisted of questions about the subjective self-assessment of personal swimming skills and knowledge of safe swimming and safe conduct at the water. Research sample included I-IVth form students, $\mathrm{n}=949$ (459 girls and 490 boys). The research results were analysed using statistical methods and SPSS 15.0 for Windows.

Results. Statistical data analysis showed the facts that during the period of 2000 to 2012, deaths of 487 children and youths (19 years old and under) were caused by accidental drowning, which on average accounts for 37.5 deaths yearly; $80.3 \%$ of all drowned persons were males.

The data of the questionnaire survey showed that $67.2 \%$ of students reported that they could swim. Boys evaluated their swimming skills better than girls $\left(x^{2}=12.486 ; \mathrm{p}<.05\right)$, although in most cases they were able to swim only short distances. The knowledge of children of the same age about safe conduct at the water was not statistically different in the aspect of gender $(\mathrm{p}<.05)$ and it was correct enough. However, even $22.7 \%$ of students $(23.1 \%$ of the girls and $22.2 \%$ of the boys) would dare to swim alone if they had an inflatable wheel, mattress or other tool ( $p>.05)$.

Conclusions. Among the research participants, $30.4 \%$ of the girls and $20.4 \%$ of the boys could not swim $\left(\chi^{2}=\right.$ 12.486; $\mathrm{p}<.05$ ). Most of the students were aware of the rules of safe conduct at the water, but some of them had rather poor knowledge about this. In case of emergency in the water students would respond differently to the situation: $84.2 \%$ of the students themselves would not jump to rescue drowning people, but they would turn to adults for help or cast life-saving tools. However, part of the boys (16.6\%) were more likely than girls $(6.9 \%)$ to jump to rescue friends $(\mathrm{p}<.05)$ at the risk of their own life. Children's responses show that even in primary grades it is important to familiarise children with ways and means to rescue drowning people.
\end{abstract}

Keywords: drowning, swimming skills, water safety, self-assessment.

\section{INTRODUCTION}

$\mathrm{C}$ hildren are the future of the nation; considering this, WHO, UNICEF, European Council and other international organizations are concerned about each country's measures to provide conditions for children to grow up healthy, get appropriate education and possibility to study, to develop health and safety related habits. Lithuania is not exclusion in this, as one of the priorities of its system of education is the development of habits that would allow children to feel safe and comfortable under different conditions throughout their life. 
However, the data of WHO show 42 thousand deaths were caused by unintentional injuries in the 0-19 age group in Europe in 2004. Car accidents, fires, drowning, poisoning, falling down are the main causes of death for children and adolescents. Even 14\% of all the recorded cases were drowning (WHO European, 2009). In this context, teaching children to swim and instructing them about safe conduct at the water plays a particularly important role as a preventive means to decrease the number of cases of drowning.

The Government of the Republic of Lithuania, considering children's ability to swim as a unique and vitally important habit, approved the programme "Teaching children to swim in Lithuanian schools of general education" for the period of 2008 to 2015 as a preventive means for accidents in the water. The programme is targeted at uniting a potential of various institutions and using current swimming infrastructure as well as human resources as effectively as possible in order to reach the main aim of the programme - to teach as many Lithuanian schoolchildren as possible to swim and observe rules of safe conduct at the water.

The aim of this work was to carry out analysis of statistical data of deaths of children and young people (19 years and under) caused by drowning in the period of 2000 to 2012, as well as to establish primary grade students' knowledge levels by subjective self-evaluation of their own swimming skills and safe conduct at the water.

\section{METHODS}

Analysis of statistical data. On the basis of the data provided by the Lithuanian Department of Statistics (http://osp.stat.gov.lt/statistiniu-rodikliuanalize?id=1490\&status=A), analysis of the number of accidental drowning cases for children and young people aged 19 years and under during the period of 2000 to 2012 was carried out.

Questionnaire survey was used to collect data on students' subjective self-evaluation of their swimming skills, as well as their knowledge about safe conduct at the water. A special questionnaire was developed for the research following the compulsory recommendations and requirements. The questionnaire was approbated by Lithuanian Swimming Federation specialists and the study was approved by the Department of Physical Education and Sports under the Government of the Republic of Lithuania (hereinafter - Department of Physical
Education and Sports). Eighteen questions were included into the questionnaire concentrating on respondents' subjective self-evaluation of personal swimming skills as well as on their knowledge about safe conduct at the water. Anonymous questionnaire survey was carried out in May, 2012, prior to the beginning of the Department of Physical Education and Sports supported programme for teaching schoolchildren to swim. All the respondents participated in the research on voluntary basis, with the approval of their school administration and parents. At first, pupils were informed about the aim of the research and instructed how to fill in the questionnaire. They were asked to answer the questions independently and honestly. Average duration of filling in the questionnaire was 15 to 20 minutes. The investigated group included the children from I-IVth grades of Kaunas, Šakiai, Šiauliai, Prienai, Vievis, Kaišiadorys, Utena and Druskininkai schools, participating in the Department of Physical Education and Sports supported programme projects. The results of the survey were processed applying the $\%$ age analysis criteria in different gender groups. Chi square $\left(\chi^{2}\right)$ criterion was used to validate the significance of differences in the results.

To validate statistical hypothesis, significance level $\mathrm{p}<.05$ was applied.

\section{RESULTS}

Analysis of the accidental drowning data for children and youth in the group of the investigated persons aged 1 to 19 years produced 487 recorded cases in 2000 to 2012, 37.5 cases per year on average. Average annual records in separate age groups were the following (respectively): from 1 to 4 years -9.1 cases, from 5 to 9 years -7.9 cases, from 10 to 14 years -6.9 cases, from 15 to 19 years -13.5 cases (Figure 1).

As to gender, the numbers of drowning cases were 4 times greater for male persons $(80.3 \%)$ than female (19.7\%). Drowning explains $15.6 \%$ of all external death cases. The data analysis of different age groups demonstrated the greatest $\%$ age of all the drowned persons being from 15 to 19 years olds (36.1\%) (Figure 2).

Questionnaire survey aimed at establishing children's self-assessment of their ability to swim as well as their knowledge about safe conduct at the water. The results of the survey demonstrated that subjectively assessing their swimming skills, even $67.2 \%$ of the respondents stated they were 


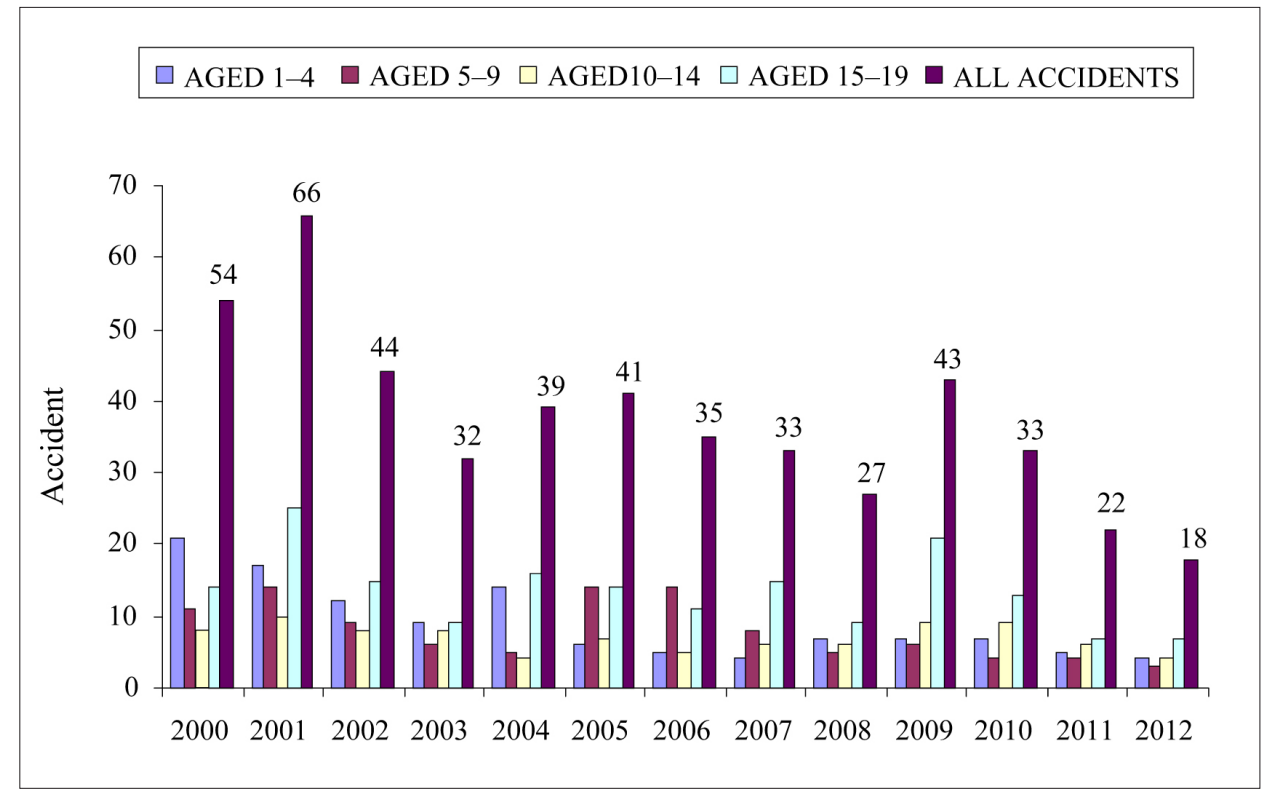

Figure 1. Statistics of accidental drowning of children and youth aged from 1 to 19 years, in the period from 2000 to 2012 (number of cases)

\section{$\square$ AGED 0-1 $\square$ AGED 1-4 $\square$ AGED 5-9 $\square$ AGED 10-14 \AGED 15-19}

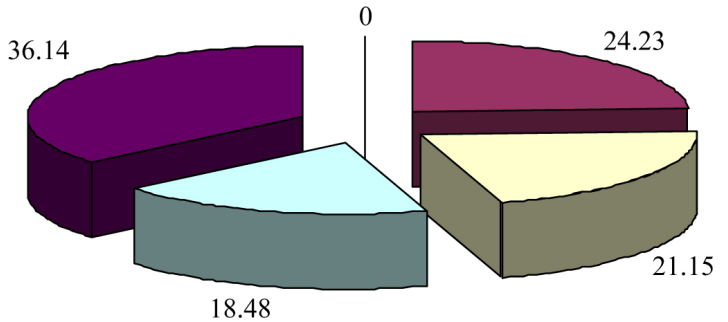

Figure 2. Percentage distribution of accidental drowning cases according to the age of children and youth

able to swim; $25.6 \%$ reported their inability to swim, while $7.2 \%$ of the respondents could not assess their swimming skills. In the aspect of gender, statistically significant differences were established: $30.4 \%$ of the girls and $20.4 \%$ of the boys reported that they could not swim $\left(\chi^{2}=\right.$ 12.486; $\mathrm{p}<.05$ ).

Aiming at finding out schoolchildren's perceptions of the statement "I can swim", they were asked to point out the distance which they would be able to overcome by swimming in a more detailed way: "I can swim the distance similar to a sports hall", "I can swim the distance similar to a classroom", "I can't swim". Following the answers to such statements, $35.7 \%$ of children pointed out that they were able to swim the distance close to a sports hall, $40 \%$ of them indicated the distance similar to a classroom, and $24.3 \%$ of them reported their inability to swim. The results show that the boys more $(42.3 \%)$ than the girls $(29.6 \%)$ think they can swim a longer distance (similar to a sports hall). More girls (43.7\%) than boys $(36.2 \%)$ stated that they could swim a shorter distance (similar to a classroom $)\left(\chi^{2}=16.603 ; \mathrm{p}<.05\right)$. However, the interviews with swimming instructors showed that starting their participation in the swimming programme, students can hardly stay up in the water and are not able to swim longer distances during their first practice sessions. This has been also confirmed by the research of Grigonienè and others (2009) showing that children who think they can swim in fact are able to cover only some meters in the water, and very few of them can swim a $50 \mathrm{~m}$ distance.

Answering the question "In your opinion, can children go into the water alone, without the 
supervision of adults?", $95.4 \%$ of the schoolchildren (96.3\% of the girls and $94.3 \%$ of the boys) agreed that children could not go into the water alone. Rather few children, $3.4 \%$ (2.2\% of the girls and $4.6 \%$ of the boys), were self-reliant and thought that they could go into the water alone. There was no statistically significant difference between the girls' and the boys' answers $\left(\chi^{2}=4.131 ; \mathrm{p}>.05\right)$. However, even $22.7 \%$ of the respondents $(23.1 \%$ of the girls and $22.2 \%$ of the boys) would go into the water alone if they had inflatable wheels, mattresses or other tools; the\%age of girls keeping to that opinion was slightly greater than that of boys. Nevertheless, the majority of the children $-71.0 \%$ (69.6\% of the girls and $72.5 \%$ of the boys) thought that going into the water alone was dangerous, even with inflatable tools; $6.3 \%$ of the respondents were not sure if they could go into the water alone even with inflatable tools $\left(\chi^{2}=2.047 ; \mathrm{p}>.05\right)$.

Most pupils (95.1\% of the girls and $94.1 \%$ of the boys) were aware that swimming was not allowed straight after meal. This is one of the rules of safe conduct at the water. According to the recommendations of swimming specialists, the interval between having a meal and swimming should be no less than 60 minutes (Skyrienè \& Tarūtiene, 2004). Only $1.7 \%$ of the pupils $(1.2 \%$ of the girls and $2.2 \%$ of the boys) saw no danger in going into the water straight after a meal $\left(\chi^{2}=\right.$ $1.305 ; \mathrm{p}>.05)$.

The children admit that during their stay in the water, eating and chewing gum is prohibited because of the risk of a choke. Only $0.8 \%$ of the girls and $1.7 \%$ of the boys thought that chewing gum in the water was not dangerous $\left(\chi^{2}=1.647\right.$; $\mathrm{p}>.05$ ).

Bathing in the sea, lake or river under unfavourable weather conditions (strong wind, rain, lightening) is dangerous, and $98.8 \%$ of the pupils were aware of this information. Comparison of girls' $(99.2 \%)$ and boys' $(98.5 \%)$ answers did not reveal significant differences $\left(\chi^{2}=2.022 ; \mathrm{p}>.05\right)$.

Answers to the question "Is it safe to walk and play on a frozen river, lake or pond" showed that $94 \%$ of children $(94.9 \%$ of the girls and $93 \%$ of the boys) knew it was unsafe; $2.5 \%$ of children would have enough courage to walk on the frozen water, while $3.5 \%$ could not tell how they would behave. The answers were not significantly different between the groups of the girls and the boys $\left(\chi^{2}=\right.$ $1.547 ; \mathrm{p}>.05)$.

It was interesting to learn about schoolchildren's possible behaviours if their friends accidently found themselves in the water under ice. Almost half of the respondents (44.7\%) $(45.5 \%$ of the girls and $43.8 \%$ of the boys) would not move towards the ice-hole, instead they would pass a stick or other thing to a friend for assistance thus rendering help. As many as $4.7 \%$ of the girls and $5.9 \%$ of the boys would not be afraid and they would try to help their friends giving them a hand; $37.3 \%$ of the children thought that they would not be able to help a friend, and they would rather turn to adults for help. Even $10.6 \%$ of the children would call Single Emergency Call Number 112. The rest $2.2 \%$ of the respondents marked the answer "I don't know" or "other" $\left(\chi^{2}=\right.$ 4.025; $p>.05$ ).

Analysis of the results, provided by the children's answers to the question "What would you do if you saw your friend drowning?", showed that $84.2 \%$ of children $(88.6 \%$ of the girls and $79.5 \%$ of the boys) would throw some unsinkable device or tool to a friend and would run to adults for help; $6.9 \%$ of the girls and $16.6 \%$ of the boys were self-reliant, they would jump into the water to help their friend, $0.6 \%$ of the respondents would run home, and $2.1 \%$ would not know what to do $\left(\chi^{2}=21.958 ; \mathrm{p}<.05\right)$.

According to the results of the answers to the question "Do you feel you can swim well enough to be able to render help to drowning friend?", 49.2 of the boys and 38.2 of the girls thought that they could swim well and could help their drowning friend; $44.5 \%$ of the girls and $35.3 \%$ of the boys did not feel strong enough to render help to a drowning friend themselves, while $16.4 \%$ of the respondents (17.3\% of the girls and $15.5 \%$ of the boys) would admit to be rather weak swimmers in this situation $\left(\chi^{2}=12.192 ; \mathrm{p}<.05\right)$.

Even $70.2 \%$ of the girls and $75.6 \%$ of the boys thought that ability to swim was very important; $26.1 \%$ of the girls and $20.3 \%$ of the boys reported swimming habit to be important enough, and only $3.9 \%$ did not see much importance of it $\left(\chi^{2}=5\right.$; $\mathrm{p}>.05)$.

\section{DISCUSSION}

Swimming and other entertainment at the water give pleasure to the majority of children; it is the source of joy and positive emotions. However, each year in Europe number of cases of drowning children exceeds 500, which is on average 14 drowned children yearly. Drowning not causing death occurs at least twice often. The latter is dangerous because it might cause a long- 
term disability including brain violation, memory or learning ability disorders, or temporary loss of the main body functions (Meyer, Theodorou, \& Berg, 2006). Lithuania is in a leading position in Europe according to the number of drowned children (Sethi, Towner, Vincenten, Segui-Gomez, Racioppi, \& Sethi, 2008).

Thegreatestdrowning riskisfaced by peoplewho cannot swim and get into the water. Nevertheless, dangers can await people who can swim as well, in particular the ones whose behaviours at the water are risky and irresponsible. Due to unsafe conduct at the water, at the beginning of the swimming season in open waters, many severe injuries occur. Disasters occur when the swimming environment and personal capacities are inadequately estimated. Often people get injuries when jumping into the water in shallow places, especially jumping into the water head down. Integral part of children and adults' teaching swimming process is the development of their habits of safe conduct at the water (Bielec \& Saklak, 2013).

Although teaching swimming is included into General Programmes of Lithuanian General Education (2011), swimming lessons do not receive sufficient attention yet. The Program of teaching schoolchildren to swim receives allocations from the budget of Department of Physical Education and Sports, as well as from the budgets of certain Lithuanian municipalities concerned, however, the programme still lacks professional coordination and sufficient financing. During summer holiday programmes, children are taught to swim only in educational institutions with active management traditions, or the activity is run by the administration of swimming facilities (Zuozienè, Kavaliauskas, Skyrienè, Grigonienè, \& Pečiūnas, 2007).

The results of the questionnaire survey carried out in 2012, showed that prior to beginning of the programme funded by the Department of Physical Education and Sports, many schoolchildren were aware of some rules of safe conduct at the water. The comparison of girls' and the boys' answers about safe conduct at the water allows suggesting that opinions of schoolchildren of the same age do not differ in the aspect of gender $(\mathrm{p}>.05)$. However, boys gave higher evaluations to their swimming skills than girls $\left(\chi^{2}=12.486 ; \mathrm{p}<.05\right)$, although in fact most often they could swim only short distances. Boys (16.6\%) more often than girls $(6.9 \%)$ would jump into the water to save their friend $\left(\chi^{2}=21.958 ; \mathrm{p}<.05\right)$. They feel more confident in the water and very often too much rely on their abilities. Thus it is important to explain to the children that saving a drowning person is not an easy task, which requires much physical effort and good swimming skills. According to statistical data, male persons are at a higher risk of drowning than the female ones. Such tendencies are observed both in Lithuania and other countries (Sethi et al., 2008).

Analysis of the cases of drowning in the group of children and youths under 19 years of age, as well as discussions of the means of prevention of such cases place teaching swimming to an important position. In the United Kingdom, which is considered to be one of the most successful countries in drowning prevention, much attention is given to teaching children to swim. The country implements the programme "Swim 4 Free", and swimming lessons are included into school curriculum together with the requirements for all children to be able to swim a 25 meter distance.

Children swimming programmes are carried out in many countries of high economy level. Swimming lessons are compulsory in Austria, Belgium, Check Republic, Estonia, Sweden (MacKay \& Vincenten, 2007). Starting from 5 years of age, children have a possibility to learn to swim and improve their swimming skills. During swimming lessons, children are taught to dive, swim underwater, breath correctly and keep vertical position in water. WHO promotes the notion of teaching children to swim considering it as a component for safety in the water, altogether reminding that being able to swim does not itself guarantee drowning prevention.

Thus children and adults' safe and responsible conduct at the water, at open water resources, proper exploitation of swimming pools, preparation of lifeguards, qualified assistance of lifeguards and medical personnel in case of accident in the water is very important (Brenner, 2003; Li Yang, QuanQing Nong, Chun-Ling Li, Qi-Ming Feng, \& Sing Kai Lo, 2007).

\section{CONCLUSIONS}

1. Statistical data analysis demonstrated that in Lithuania, during the period of 2000 to 2012, unintentional drowning were the death causes for 487 children and youths (aged 19 and under), which on is 37.5 cases yearly average. Even $80.3 \%$ of all the drowned children were boys. 
2. As many as $30.4 \%$ of the girls and $20.4 \%$ of the boys who participated in the research reported that they were not able to swim. The students, having indicated their ability to swim, very often tended to overestimate their personal swimming skills.

3. Analysis of students' knowledge about safe conduct at the water showed that the majority of them were aware of it; however, some students possessed poor knowledge in this field. No significant differences were established between gender groups.
4. In case of accident in the water, students would respond differently to the situation: $84.2 \%$ of them would not jump straight into the water to render help, but they would rather address adults for assistance or pass tools to a drowning person for rescue. However, some boys (16.6\%) and girls $(6.9 \%)$, saving a friend, would jump into the water, thus risking their lives. Children's responses show that even in primary grades it is important to teach children to swim and familiarise them with ways and means of rescueing drowning people.

\section{REFERENCES}

Bielec, G., \& Saklak, W. (2013). Swimming classes in junior high school students' opinion. Pedagogics, Psychology, Medical-Biological Problems of Physical Training and Sports, 2, 92-98. doi:10.6084/ m9.figshare. 639260

Brenner, R. (2003). Prevention of drowning in infants, children, and adolescents. Pediatrics, 112, 440-445.

Grigoniene, J. J., Skyrienè, V., Zuozienè, I. J., Kavaliauskas, S., \& Pečiūnas, E. (2009). Mokymas plaukti - sveikatinimas ir gyvybiškai svarbaus igūdžio formavimas. Mokslinių straipsniu rinkinys. Sportini darbingumą lemiantys veiksniai (II). P. 120-128.

Lietuvos statistikos departamentas. (2013). Retrieved from: http://osp.stat.gov.lt/statistiniu-rodikliu-analize?id $=1490 \&$ status $=$ A

Li Yang, Quan-Qing Nong, Chun-Ling Li, Qi-Ming Feng, \& Sing Kai Lo. (2007). Risk factors for childhood drowning in rural regions of a developing country: A case-control study. Injury Prevention, 13(3), 178-182.

MacKay, M., \& Vincenten, J. (2007). Child safety summary report card for 18 countries - 2007. Amsterdam: European Child Safety Alliance.
Meyer, R. J., Theodorou, A. A., \& Berg, R. A. (2006). Childhood drowning. Pediatrics in Review, 27, 163-169.

Sethi, D., Towner, E., Vincenten, J., Segui-Gomez, M., \& Racioppi, F. (2008). European report on child injury prevention. World Health Organization. P. 98. Retrieved from: http://www.euro.who.int/en/what-wedo/health-topics/Life-stages/child-and-adolescent-health/ publications/2008/european-report-on-child-injuryprevention

Skyrienè, V., \& Tarūtienè, S. (2004). Mokome plaukti ir saugiai elgtis vandenyje: mokomoji knyga. Vilnius: Lietuvos sporto informacijos centras.

Vidurinio ugdymo bendrosios programos (General Programs of Lithuanian General Education). (2011). Vilnius. Retrieved from: http://www.upc.smm.lt/ suzinokime/bp/2011/

WHO Media centre. Drowning. (2014). Fact sheet N³47. Updated April 2014. Retrieved from: http:// www.who.int/mediacentre/factsheets/fs347/en/

Zuozienè, J. I., Kavaliauskas, S., Skyrienè, V., Grigonienè, J. J., \& Pečiūnas, E. (2007). Mokymas plaukti: realijos ir perspektyvos. Vilnius: Kūno kultūros ir sporto departamentas. 